\title{
INFLUENCE OF PERSONAL VALUES ON CONSUMER CHOICE AND INTENTION TO BUY: A CASE OF CROATIAN AUTOMOBILE MARKET
}

\author{
Ivana Tonković Pražić1
}

DOI: https://doi.org/10.31410/ITEMA.S.P.2020.117

\begin{abstract}
This paper aimed to identify the factors and segments of car buyers based on their personal values and analyzing their relation to car buyers' choice and intention to buy. A survey involving 561 participants was conducted using the PVQ scale and additional questions about car-buying behavior. Upon collecting the data, statistical analysis was conducted that allowed for nine value types to be successfully distinguished among car buyers: benevolence, universalism, self-direction, stimulation, hedonism, achievement, and power, security, conformity, and tradition. Additionally, based on the abovementioned value types, different consumer segments were distinguished: "opened to change", "self-transcendent", "selfenhanced" and "conservative". Furthermore, the results show that segments of car buyers differ in their preferences of car models, i.e. they choose or intend to buy different car models. The conclusion presents the contribution of the paper, limitations, and guidelines for future research.
\end{abstract}

Keywords: Personal value types, Segments of car buyers, Car buying intention.

\section{INTRODUCTION}

7 he fact that personal values play a pivotal role in predicting human behavior has been accepted by authors of various scientific disciplines, including marketing. Relevant researchers have shown that individuals use personal values as a basis for forming their attitudes, intentions, assessments, comparisons, activities, and decisions, regardless of the specific object or situation (Burgess, 1992). Schwartz (1994) defines human values as motivational constructs that are related to desirable nonspecific goals, which differ in importance, and serve as guiding principles in the life of an individual or social entity. Personal values can serve to clarify the motives of consumer behavior because they serve individuals as criteria of behavior, are limited in number, and are extremely stable over time (Rokeach, 1973).

Marketing research on personal values proved that personal values affect various aspects of consumer behavior, such as ethical consumption (Shaw et al., 2005), perception of product or brand position (Da Silva Añaña and Nique, 2007) preferences for salty snacks (Perkins and Reynolds, 1988, Dibley and Baker, 2001), purchase of gifts (Beatty, Kahle and Homer, 1991), etc., but the influence of personal values on behavior related to car buying has not been investigated to an acceptable degree.

1 Polytechnic Nikola Tesla in Gospić, Bana Ivana Karlovića 16, Gospić, Croatia 


\section{LITERATURE REVIEW}

The most influential author in the field of values is Schwartz, who not only defined personal values but also proposed one of the most influential theories of the universal content and the structure of human values and designed measuring instruments to investigate human values (Burgess and Harris, 1998). The final result of Schwartz's value analysis is the successful separation of four higher-level value dimensions that encompass ten value types and represent the opposite poles of the two dimensions - self-transcendence versus self-enhancement, and openness to change versus conservation. (Schwartz, 1992)

Schwartz also developed the Portrait Values Questionnaire (PVQ), an instrument for measuring personal values whose validity has been successfully confirmed in surveys conducted in 18 countries (on 31 samples). One of the main advantages of this measuring instrument is its flexibility since it can be carried out in person, in writing, by telephone, or via the Internet (Schwartz, 2003). PVQ consists of 40 statements/descriptions of persons, and respondents can express their similarity to the described person by five degrees (Schwartz, 2003). The abovementioned was the reason why PVQ was considered adequate and therefore used as a measuring instrument in this research.

Further analysis of the marketing literature in the field of personal values indicated the need to investigate differences between consumers based on their personal values in order to provide additional insight into the motivations of different consumer groups to buy or their intention to buy certain products (Sukhdial, Chakraborty and Steger, 1995). Also, there was a need to understand the differences in the context of buying/consuming certain products between consumer segments distinguished based on personal values (de Juan Vigaray and Hota, 2008). Finally, Vinson, Scott and Lamont (1977) point to the need to extract consumer segments in a population-based on their personal values, and to investigate differences in the assessment of attributes and product classes (they emphasized cars) between such segments.

Considering all the above mentioned, this paper attempted to answer the question of whether and to what extent personal values affect the purchase of durable goods, i.e. cars. Specifically, this paper aimed to discover whether the research into personal values of car buyers can result in identifying distinct consumer segments which would differ in their intentions to buy and also own different car makes.

\section{RESEARCH METHODOLOGY}

The sample consisted of car buyers from the Republic of Croatia and only respondents who bought a personal vehicle within the last five years were considered. The survey, based on PVQ, was conducted on a sample of 561 respondents selected using the random stratified sample method. Respondents were mostly contacted by telephone, while many surveys were completed online.

After conducting the survey, the collected data was analyzed using several statistical methods. These methods include the Cronbach's Alpha reliability coefficient, the factor and cluster analysis method, the variance analysis method (ANOVA), and the application of crosstabulation. The Cronbach's Alpha coefficient was used in order to verify the reliability and validity of the measuring scale. An exploratory and confirmatory factor analysis was performed to assess the validity (convergent and discriminant) and extract factors of values from the total number of claims. After extracting personal value factors, cluster analysis (K- 
means method) was performed. Finally, analysis of variance (ANOVA) and crosstabulation was performed, in order to identify the connection between distinguished clusters/segments of car buyers and their car make ownership or intention to buy.

\section{ANALYSIS AND RESULTS}

Before conducting exploratory and confirmatory factor analysis in order to identify the underlying structure of personal values, the suitability of the collected data for factor analysis was examined. The Keiser-Meyer-Olkin test measuring the adequacy of sampling produced a value of 0,812 thus providing evidence that the sample is adequate for further factor analysis. Also, the results of the Bartlett test of sphericity $(\mathrm{p}=0,000)$ indicated the appropriateness of the factor model for the data set. Based on Kaiser's rule of selection, nine factors were extracted (explained variance of the manifest variables $64,65 \%$; $\mathrm{p}=0,000$ ).

The first of the nine extracted factors was named achievement and power since it described behavior connected with obtaining ,social status and prestige“ but also ,personal success through demonstrating competence according to social standards" (Schwartz, 2003, p. 267). The next factor is named hedonism since it points individuals towards ,pleasure“ and achieving „sensuous gratification for oneself“ (Schwartz, 2003, p. 267). Stimulation is a factor that incites the need for „excitement, novelty, and challenge in life“ (Schwartz, 2003, p. 267). One considers ,independent thought, creating and exploring“ (Schwartz, 2003, p. 268) important if one emphasizes the value factor of self-direction. The next factor is universalism, and it encompasses ,understanding, appreciation, tolerance, and protection for the welfare of people and nature" (Schwartz, 2003, p. 268). Benevolence is a value factor that directs individuals towards ,,preservation and enhancement of the welfare of people with whom one is in frequent personal contact" (Schwartz, 2003, p. 268). If one values tradition, one holds in high regard „commitment to the customs and ideas that traditional culture or religion provide“" (Schwartz, 2003, p. 268). The next factor promotes, ,restraint from actions that are likely to upset or harm others and violate social norms" (Schwartz, 2003, p. 268), which is why it is called conformity. Finally, the ninth factor is named security, and it promotes actions that ensure ,safety, harmony and stability of society, relationships and oneself" (Schwartz, 2003, p. 268).

In order to segment car buyers, cluster analysis (K-means) was used. Four segments were distinguished with the analysis, and the results are shown in table 1.

Table 1. Results of cluster analysis of car buyers, mean segment values and F-ratio

\begin{tabular}{|c|c|c|c|c|c|c|}
\hline Variables & $\begin{array}{c}\text { Opened } \\
\text { to change }\end{array}$ & $\begin{array}{c}\text { Self- } \\
\text { enhanced }\end{array}$ & $\begin{array}{c}\text { Self- } \\
\text { transcendent }\end{array}$ & Conservative & $\begin{array}{c}\text { F- } \\
\text { ratio }\end{array}$ & P \\
\hline Benevolence & 19,69 & 18,04 & 20,71 & 20,50 & 23,829 & 0,00 \\
\hline Self-direction & 17,27 & 16,94 & 16,46 & 16,99 & 30,640 & 0,02 \\
\hline Stimulation & 11,31 & 11,03 & 9,78 & 10,29 & 12,358 & 0,00 \\
\hline Hedonism & 11,44 & 12,27 & 9,45 & 10,50 & 30,426 & 0,00 \\
\hline Achievement and power & 21,78 & 29,57 & 14,10 & 21,63 & 59,389 & 0,00 \\
\hline Security & 15,41 & 18,24 & 18,04 & 20,99 & 89,071 & 0,00 \\
\hline Conformity & 13,90 & 14,54 & 16,04 & 17,63 & 61,441 & 0,00 \\
\hline Tradition & 9,97 & 11,67 & 12,76 & 15,03 & 73,871 & 0,00 \\
\hline Universalism & 16,61 & 15,08 & 17,75 & 17,71 & 39,417 & 0,00 \\
\hline
\end{tabular}

Source: adapted from Tonković Pražić (2018) 
As can be seen in table 1, the first of the extracted segments comprises the value types of selfdirection and stimulation which makes it similar to one of Schwartz's value dimensions, which is called "openness to change" and thus this segment of car buyers is named opened to change. In the second segment, the factor achievement and power, as well as hedonism, has a higher average score. The aforementioned value types correspond to the value dimension of selfenhancement which is why this segment was called self-enhanced. Because it encompasses the value types of benevolence and universalism the third segment of car buyers is named selftranscendent due to the fact that the said values can be related to Schwartz's value dimension of self-transcendence. Finally, according to the cluster analysis, the value types security, conformism, and tradition were extracted in the fourth segment, so this segment is called conservative.

In order to examine whether the selected segments of car buyers differ significantly according to characteristics related to buying and owning a car, i.e. the car makes a respondent owns and intends to buy, ANOVA analysis was used. The results of the conducted analysis are presented in table 2.

Table 2. Results of ANOVA analysis

\begin{tabular}{|c|c|c|}
\hline Car buyers' segments & Car makes owned & Car makes intended to buy \\
\hline & $\begin{array}{r}\mathrm{F}=0,270 \\
\mathrm{p}=0,847\end{array}$ & $\begin{array}{l}\mathrm{F}=4,758 \\
\mathrm{p}=0,003\end{array}$ \\
\hline Opened to change & 5,723 & 7,608 \\
\hline Self-enhanced & 5,582 & 6,555 \\
\hline Self-transcendent & 5,695 & 8,791 \\
\hline Conservative & 5,676 & 8,728 \\
\hline
\end{tabular}

Source: author's calculations

According to table 2, car buyer segments' differences are statistically significant when the observing car makes respondents are intending to buy. In other words, members of a particular segment of car buyers do not intend to buy the same car makes as the other car buyers. On the other hand, there is no statistically significant difference between segments based on the car makes the respondents currently own.

The differences between segments based on their car make ownership and intention to buy were analyzed with crosstabulation and Pearson's chi-squared test and the results are presented in table 3.

Table 3. Car makes buyers currently own and intend to buy

\begin{tabular}{|c|c|c|c|c|c|}
\hline Car Makes & \multicolumn{4}{|c|}{ \% Within Cluster Number of Case } & \multirow{3}{*}{$\begin{array}{c}\text { \% Within } \\
\text { Cluster } \\
\text { Number of } \\
\text { Case }\end{array}$} \\
\hline Owned & \multirow{2}{*}{$\begin{array}{l}\text { Opened to } \\
\text { change }\end{array}$} & \multirow{2}{*}{$\begin{array}{c}\text { Self- } \\
\text { enhanced }\end{array}$} & \multirow{2}{*}{$\begin{array}{c}\text { Self- } \\
\text { transcendent }\end{array}$} & \multirow{2}{*}{ Conservative } & \\
\hline Intended & & & & & \\
\hline \multirow{2}{*}{ Alfa Romeo } & 0,7 & 0,0 & 0,0 & 1,4 & 0,6 \\
\hline & 0,7 & 0,0 & 1,5 & 0,0 & 0,6 \\
\hline \multirow{2}{*}{ Audi } & 3,3 & 0,0 & 4,8 & 2,9 & 3,0 \\
\hline & 6,8 & 0,0 & 3,8 & 4,8 & 4,2 \\
\hline \multirow{2}{*}{ BMW } & 2,0 & 4,2 & 1,4 & 2,0 & 1,9 \\
\hline & 3,4 & 14,1 & 3,1 & 4,0 & 5,5 \\
\hline Chevrolet & 2,0 & 1,1 & 3,4 & 0,7 & 1,9 \\
\hline
\end{tabular}


INFLUENCE OF PERSONAL VALUES ON CONSUMER CHOICE AND INTENTION TO BUY: A

\begin{tabular}{|c|c|c|c|c|c|}
\hline & 0,0 & 0,0 & 3,1 & 2,4 & 1,4 \\
\hline Chrysler & 0,0 & 0,0 & 1,4 & 0,7 & 0,6 \\
\hline \multirow{2}{*}{ Citroen } & 3,9 & 7,4 & 5,4 & 7,2 & 5,8 \\
\hline & 1,4 & 0,0 & 0,0 & 2,4 & 1,0 \\
\hline \multirow{2}{*}{ Dacia } & 0,7 & 2,1 & 0,7 & 0,0 & 0,7 \\
\hline & 1,4 & 0,0 & 0,0 & 1,6 & 0,8 \\
\hline Daewoo & 0,0 & 0,0 & 1,4 & 0,7 & 0,6 \\
\hline \multirow{2}{*}{ Fiat } & 2,0 & 1,1 & 2,0 & 2,9 & 2,1 \\
\hline & 0,0 & 3,3 & 0,0 & 1,6 & 1,0 \\
\hline \multirow{2}{*}{ Ford } & 3,9 & 2,1 & 4,8 & 5,8 & 4,3 \\
\hline & 0,7 & 3,3 & 0,7 & 3,3 & 2,0 \\
\hline \multirow{2}{*}{ Honda } & 2,0 & 0,0 & 2,0 & 0,7 & 1,3 \\
\hline & 0,7 & 0,0 & 0,0 & 1,6 & 0,6 \\
\hline \multirow{2}{*}{ Hyundai } & 3,9 & 0,0 & 2,0 & 1,4 & 2,1 \\
\hline & 2,0 & 0,0 & 2,3 & 2,4 & 1,8 \\
\hline \multirow{2}{*}{ Kia } & 0,7 & 2,1 & 5,4 & 0,7 & 2,2 \\
\hline & 0,0 & 2,2 & 3,1 & 0,0 & 1,2 \\
\hline \multirow{2}{*}{ Mazda } & 2,6 & 4,2 & 2,7 & 0,7 & 2,4 \\
\hline & 0,7 & 3,3 & 0,8 & 2,4 & 2,4 \\
\hline \multirow{2}{*}{ Mercedes } & 1,8 & 2,2 & 1,0 & 0,0 & 1,3 \\
\hline & 1,4 & 6,5 & 2,3 & 1,6 & 2,6 \\
\hline \multirow{2}{*}{ Mitsubishi } & 1,3 & 1,1 & 1,4 & 0,0 & 0,9 \\
\hline & 0,0 & 0,0 & 3,1 & 0,0 & 0,8 \\
\hline Nissan & 2,6 & 2,1 & 1,4 & 1,4 & 1,9 \\
\hline \multirow{2}{*}{ Opel } & 11,1 & 14,7 & 5,4 & 13,7 & 10,9 \\
\hline & 2,7 & 4,3 & 6,2 & 10,3 & 5,9 \\
\hline \multirow{2}{*}{ Peugeot } & 7,8 & 4,2 & 4,8 & 2,9 & 5,1 \\
\hline & 0,7 & 1,1 & 1,5 & 1,6 & 1,2 \\
\hline \multirow{2}{*}{ Renault } & 5,2 & 3,2 & 3,4 & 7,9 & 5,1 \\
\hline & 2,0 & 0,0 & 6,2 & 1,6 & 2,6 \\
\hline Seat & 1,3 & 1,3 & 0,0 & 0,0 & 0,7 \\
\hline \multirow{2}{*}{ Suzuki } & 0,7 & 0,0 & 0,7 & 2,2 & 0,9 \\
\hline & 0,0 & 0,0 & 0,0 & 0,8 & 0,2 \\
\hline \multirow{2}{*}{ Škoda } & 3,9 & 2,2 & 0,0 & 2,2 & 2,2 \\
\hline & 6,1 & 0,0 & 0,8 & 0,8 & 2,2 \\
\hline \multirow{2}{*}{ Toyota } & 3,3 & 2,1 & 3,4 & 2,9 & 3,0 \\
\hline & 2,0 & 5,4 & 5,3 & 1,6 & 3,4 \\
\hline \multirow{2}{*}{ Volkswagen } & 9,2 & 11,6 & 13,6 & 10,1 & 11,0 \\
\hline & 13,6 & 12,0 & 10,0 & 7,1 & 10,7 \\
\hline \multirow{2}{*}{ Volvo } & 0,0 & 1,1 & 0,7 & 0,0 & 0,4 \\
\hline & 0,7 & 2,2 & 0,0 & 0,0 & 0,6 \\
\hline Do not know & 53,1 & 41,3 & 46,2 & 48,4 & 47,0 \\
\hline \multirow{2}{*}{ Chi Squared } & & & & & 0,164 \\
\hline & & & & & 0,000 \\
\hline
\end{tabular}

Source: author's calculations (adapted from Tonković Pražić, 2018) 


\section{CONCLUSION}

Based on the results of the research, the influence of personal values on car buyers' choice and intention to buy was partially proven. It was shown that car buyers can be segmented based on their personal values and that those segments differ significantly according to the car makes they intend to buy. On the other hand, the differences based on car make ownership were existent but not statistically significant.

Segments of car buyers differ one from another based on the car model that they already own, but the difference is not statistically significant. Most respondents own a Volkswagen since it is owned by $11 \%$ of respondents, followed by Opel (10,9\%). When analyzing the differences among the segments, it can be concluded that the conservative segment is characterized by owning a car makes such as Alfa Romeo, Ford, Fiat, Opel, and Renault, while they are least likely to own a Dacia, Mercedes, Mitsubishi, Seat, and Volvo. Car buyers who are open to change are most likely to own a Honda, Hyundai, Nissan, Peugeot, Seat, and Škoda but compared to other segments of car buyers they are least likely to own a Chrysler, Daewoo, or Volvo. As far as the self-enhanced segment of car buyers is concerned, the members of that segment are more likely to own a BMW, Citroen, Dacia, Mazda, Mercedes, Opel, Seat, and Volvo. On the other hand, members of this segment are not as frequently owners of Alfa Romeo, Audi, Chrysler, Daewoo, Honda, Hyundai, and Suzuki as members of other segments. Finally, self-transcendent respondents are more likely to be owners of Audi, Chevrolet, Chrysler, Daewoo, Honda, Kia, Mitsubishi, Toyota, and Volkswagen than other respondents. On the other hand, they tend to own an Alfa Romeo, Seat, and Škoda less frequently than members of other segments.

As far as the car purchase intention is concerned, most of the respondents could not say what car make they would buy next time they buy a car (47\%). But the most of the respondents who indicated their buying intentions intend to buy a Volkswagen (10,7\%). When comparing segments of car buyers, it is obvious that the conservative segment of car buyers mostly intended to buy a Citroen, Dacia, Ford, Honda, Hyundai, Ford, Opel, Peugeot, or Suzuki, while it was the opposite for Alfa Romeo, Kia, Volvo, and Mitsubishi. The self-enhanced segment of car buyers were the most numerous intended buyers of Volvo, BMW, Fiat, Ford as well as Mercedes, but they did not intend to buy a Mitsubishi, Škoda, Suzuki, Alfa Romeo, Dacia, Renault, Honda, Hyundai, Chevrolet, Audi or Citroen. Mitsubishi was the preferred choice by members of the self-transcendent segment, but also Alfa Romeo, Kia, Renault, and Chevrolet. This segment was least likely to choose a Citroen, Honda, Fiat, Dacia, Volvo, or Suzuki the next time they would buy a car. Finally, members of the open-to-change car buyers' segment were most likely to choose Škoda, Audi, or Volkswagen for their next car, while they would not opt for a Mitsubishi, Chevrolet, Fiat, Kia, or Suzuki.

Results of the conducted research may enable marketing experts to develop the more appropriate marketing and advertising strategies. Marketing experts, when planning for an advertising campaign of car makes self-transcendent car buyers intended to buy, should emphasize the positive influence of the car make on the environment and other people, maybe through social marketing actions. Self-enhanced car buyers might respond more favorably if the car makes them intended to buy displayed luxury, elegance, fun, and enjoyment with their design and marketing appeals. The car makes conservative car buyers intended to buy should have a marketing campaign that appealed to their makes' tradition, stability, and safety features. Finally, those open to change might be more prone to buying a car make if they considered it original, special, and unique. 
This research also has its limitations that need to be corrected in future research. The research was conducted on a sample of car buyers, while future research might consider looking into different samples, such as furniture or home appliances buyers, tourists, etc. Also, aspects other than ownership and intention to buy should be considered, such as buying habits, attitudes about car makes, model preferences, etc.

\section{REFERENCES}

Beatty, S.E. Kahle., L.R., \& Homer, P. (1991). Personal Values and Gift-Giving Behaviours: A Study across Cultures. Journal of Business Research, 22(2), 49-157.

Burgess, S.M. (1992). Personal Values and Consumer Research: An Historical Perspective. Research in Marketing, 11(1), 35-79.

Burgess, S.M., \& Harris, M. (1998). Values, Optimum Stimulation Levels and Brand Loyalty: New Scales in New Populations. South African Journal of Business Management, 29(4), $142-157$.

Da Silva Añaña, E., \& Nique, W.M. (2007). A Professional Category Positioning: The Role of Personal Values and Their Influence on Consumer Perceptions. Journal of Database Marketing \& Customer Strategy Management, 14, 289-296.

De Juan Vigaray, M.D., \& Hota, M. (2008). Schwartz Values, Consumer Values and Segmentation: The Spanish Fashion Apparel Case. Retrieved from http://www.ieseg.fr/enseignants-et-recherche/ieseg-research/documents-de-travail/.

Dibley, A., \& Baker, S. (2001). Uncovering the Links between Brand Choice and Personal Values among Young British and Spanish Girls. Journal of Consumer Behaviour, 1(1), 77-93.

Perkins, W.S., \& Reynolds, T.J. (1988). The Explanatory Power of Values in Preference Judgements: Validation of the Means-End Perspective. Advances in Consumer Research, $15,122-126$.

Rokeach, M. (1973). The Nature of Human Values. New York, NY: Free Press.

Schwartz, S.H. (1992). Universals in the Content and Structure of Values: Theoretical Advances and Empirical Tests in 20 Countries. Advances in Experimental Social Psychology, 25, 1-65.

Schwartz, S. H. (1994). Are There Universal Aspects in the Structure and Contents of Human Values? Journal of Social Issues, 50(4), 19-45.

Schwartz, S. H. (2003). A Proposal for Measuring Value Orientations across Nations. The Questionnaire Development Package of the European Social Survey. Retrieved from europeansocialsurvey.org.

Shaw, D., Grehan E., Shiu E., Hassan L., \& Thomson J. (2005). An Exploration of Values in Ethical Consumer Decision Making. Journal of Consumer Behaviour, 4(3), 185-200.

Sukhdial, A. S., Chakraborty, G., \& Steger, E. K. (1995). Measuring Values Can Sharpen Segmentation in the Luxury Auto Market. Journal of Advertising Research, 35, 9-19.

Tonković Pražić, I. (2018). The Influence of Personal Values on Consumer Decision-Making Styles of Buyers in the Car Market (Unpublished doctoral dissertation). Faculty of Economics, Business and Tourism in Split.

Vinson, D.E., Scott, J.E., \& Lamont, L. (1977). The Role of Personal Values in Marketing and Consumer Behavior. Journal of Marketing, 41, 44-50. 